Dawson, D. W., and Johnson, J. (1958): Anticonvulsants and Megaloblastic Anaemia, Brit. med. J., i, 397.

Girdwood, R. H., and LenMAN, J. A. R. (1956): Anaemia occurring During Primidone Therapy, Brit. med. J., i, 146.

Gough, K., Read, A., McCarthy, C., and Waters, A. (1963): Megaloblastic Anaemia due to Nutritional Deficiency of Folic Acid, Quart. J. Med. N.S., 32, 243.

Hawkins, C. F., and Meynell, M. J. (1958): Macrocytosis and Macrocytic Anaemia Caused by Anticonvulsant Drugs, Quart. Med. J., 27, 45.

MCCANCE, R. A., and WidDowson, E. M. (1960): The Composition of Foods, Spec. Rep. Ser. med.
Res. Coun. (Lond.), No. 297, London: H.M.S.O. Sherwin, A. L.. Wait, R. H., and Cooper. B. A. (1960): Megloblastic Anaemia Associated with Phenobarbital Therapy, Canad. med. Ass. J., 82, 368 .

Smith, M. D., Smith, D. A., and Fletcher, M. (1962): Haemorrhage Associated with Thrombocytopenia in Megaloblastic Anaemia, Brit. med. J., i, 982 .

VARADI, S. (1957): Megaloblastic Anaemia During Anticonvulsant Therapy, Lancet, ii, 846.

ZALUSKY, R., and HerberT, V. (1961): Megaloblastic Anaemia in Scurvy with Response to $50 \mu \mathrm{g}$. of Folic Acid Daily, New Engl. J. Med., 265, 1033.

\title{
THE ADULT FANCONI SYNDROME
}

\author{
*D. P. Mullan, M.A., M.B. (Cantab.) M.R.C.P., \\ Medical Registrar, Department of Medicine, The Royal Hospital, Sheffield.
}

THE following case demonstrates the clinical features of this condition and also the excellent response to vitamin $\mathrm{D}$ therapy. The patient, a woman of 44 , had multiple defects of tubular function, osteomalacia and numerous pseudofractures. In addition, slit lamp examination revealed a number of conjunctival and corneal crystals. She has now been followed up for fourteen months and radiological cure is almost complete. The cause of this condition in this patient remains uncertain. The urine from nine close relatives has been examined, but no abnormal aminoaciduria has yet been discovered. She has lived all her life in the same area on the north side of Sheffield, and it may be that her diet has long been poor.

\section{Case History}

The patient was first seen in October, 1963, having been referred to the medical unit by a rheumatologist. For four years she had suffered from increasingly severe bone pain affecting her shoulders, rib cage, spine and legs. Any movement, especially sitting up from a lying position was difficult. For eighteen months her gait had become waddling in character. Some two years previously she had been on small doses of prednisolone as treatment for her "rheumatism". She had complained of thirst and polyuria for four months, and she also suffered from occasional attacks of unexplained fever with headache.

There was no past history of rickets or coeliac disease. However, her obstetric history was important. She has six live children ranging from eighteen to eleven. Her first baby died aged one month with broncho-pneumonia. In February 1950, a contraction ring developed during labour and her fifth child was delivered by Caesarean Section. Proteinuria and a trace of sugar in her urine had been found one month prior to this delivery. In May 1952, on account of an

*Now Senior Medical Registrar, The Royal Hospital, Sheffield. oblique lie, her sixth child was also delivered by Caesarean Section and her tubes were then tied. Moderate proteinuria was frequently noted during this pregnancy, in the absence of obvious infection. However, there was no ankle oedema and her blood pressure was $130 / 70 \mathrm{~mm} . \mathrm{Hg}$. Radiographs of her chest and pelvis in 1950 and 1952 showed no evidence of osteomalacia.

Examination (See Fig. 1.) revealed a thin, red faced woman, who was rather deaf. She had a waddling gait. There was some shortening of her spine so that her arm span was disproportionately great. Her ribs were tender and compression of her pelvis was painful. The remaining systems were normal and her blood pressure was $130 / 110 \mathrm{~mm} . \mathrm{Hg}$.

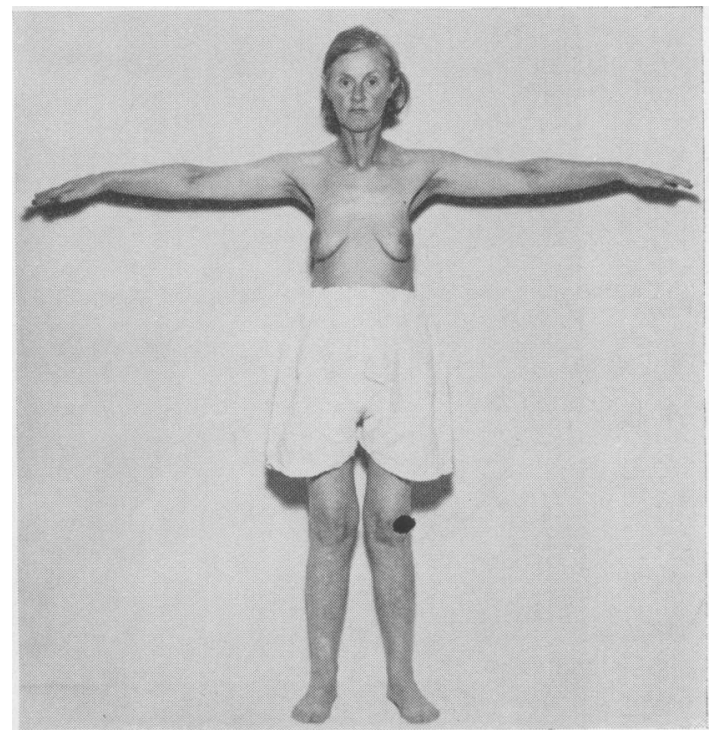

FIG. 1.--Photograph of patient. Height 4 ft. 10 ins. Span $4 \mathrm{ft}$. 10 ins. (former height $5 \mathrm{ft} .2$ ins.) Weight $33 \mathrm{Kg}$. 
Biochemical Investigations. The urine showed a persistent proteinuria of $30-300 \mathrm{mg} . / 100 \mathrm{ml}$. There was intermittent glycosuria of $\frac{1}{4}-\frac{1}{2} \%$. A glucose tolerance test showed renal glycosuria. Her blood urea varied from 40 to $72 \mathrm{mg}$./ $100 \mathrm{ml}$. and the creatinine clearance was reduced ( 31 and $24 \mathrm{ml} . / \mathrm{min}$.). She was unable to concentrate urine to a higher SG than 1010 . Plasma electrolytes: $\mathrm{Na} 133-142, \mathrm{~K} 2.7-3.5, \mathrm{Cl} 102$ -108 and alkali reserve $15-18$ m.equiv./1. In spite of a systemic acidosis, with an arterial $\mathrm{pH}$ of 7.36, the urine $\mathrm{pH}$ was 6.91. Serum calcium adjusted to serum protein was $9.0,10.4$ and $9.1 \mathrm{mg} . / 100 \mathrm{ml}$. and the corresponding levels for serum phosphate were $3.5,3.4$ and $2.4 \mathrm{mg}$. $/ 100 \mathrm{ml}$. The alkaline phosphatase was raised at 50,51 and 54 K.A. units. Her liver function tests were normal and the serum uric acid was $4.0 \mathrm{mg} . / 100 \mathrm{ml}$. A 24 -hour collection of urine $(2,300 \mathrm{ml}$.) contained $69 \mathrm{mg}$. of calcium and $920 \mathrm{mg}$. of phosphates.

Paper chromatography of her urine for amino-acids showed a generalised increase of glycine, alanine, serine, glutamine and histidine. Faint spots of leucine, valine and proline were also seen. This generalized amino-aciduria was confirmed by Professor Dent, who also found some excess of urinary cystine. In addition, electrophoresis of her urine demonstrated "tubular protein" migrating in the region of the $\gamma_{2}$ globulin (Butler and Flynn, 1958; Creeth, Kekwick, Flynn, Harris and Robson, 1963).

Slit lamp examination revealed a moderate number of crystals in the superficial layers of the cornea and also some in the conjunctiva. She was unwilling to have a conjunctival biopsy and we were therefore unable to demonstrate whether or not these were in fact cystine crystals. However, using polarized light, no cystine crystals were recognized in her bone marrow, which was normal.

Faecal fat estimation (over a five day period) was

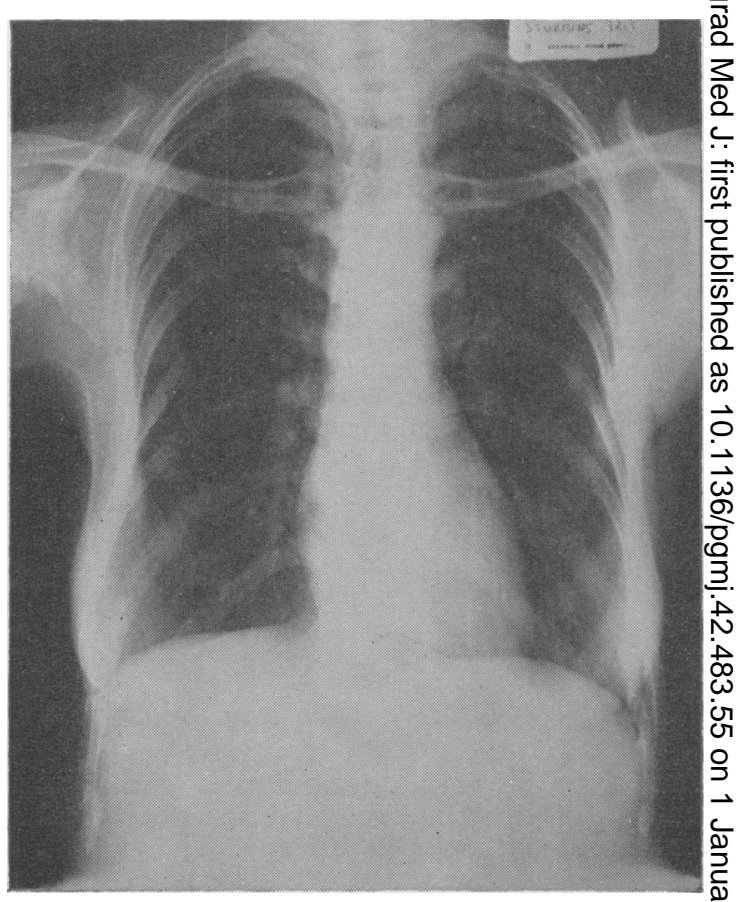

FiG. 2.-November 1963, showing bilateral pseudo fractures of the ribs.

3.5 g. fatty acid/day which excluded steatorrho Her serum electrophoretic strip was normal; theje was nothing to suggest myelomatosis. The (Wintrobe) was $4 \mathrm{~mm}$./hr. and $\mathrm{Hb} 114 \%$.

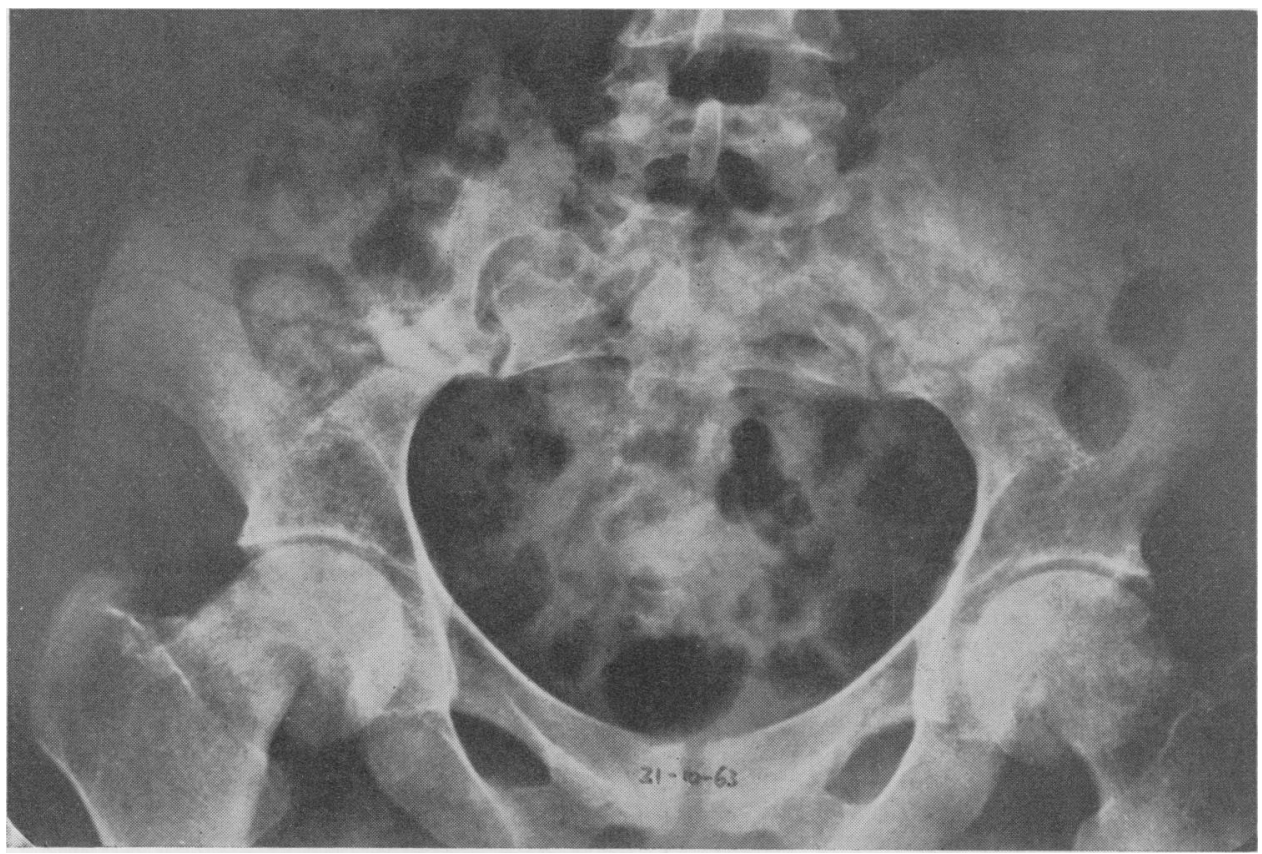

Fic. 3.- October 1963, showing a long Looser zone on the right side of the pelvis, and a smaller one on the left. The right femoral neck is displaced upwards. 


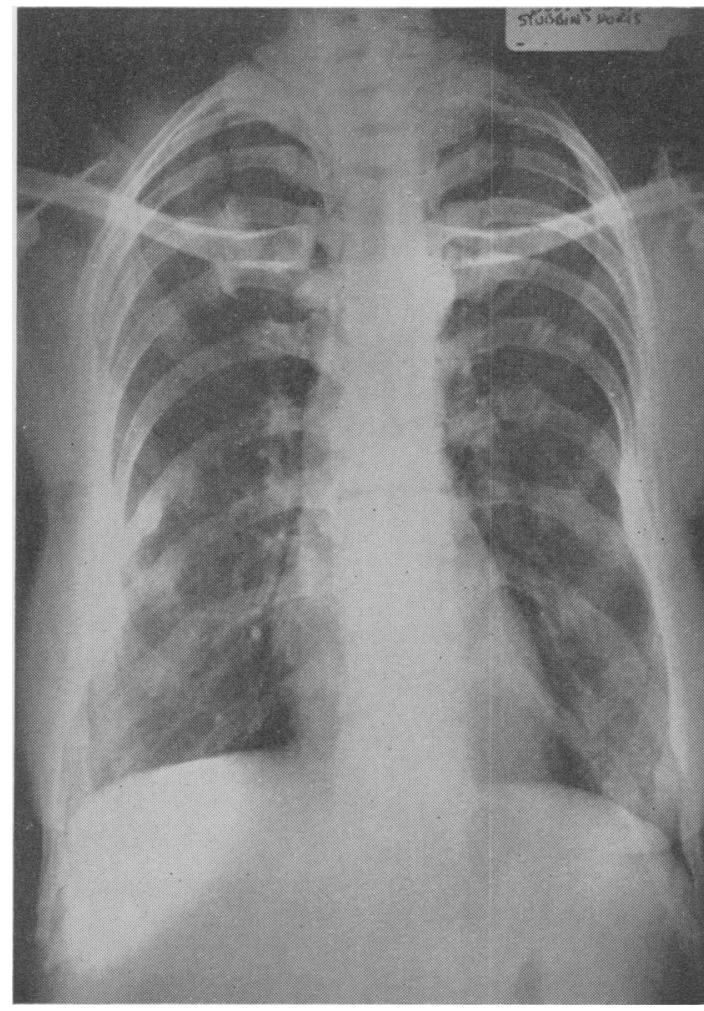

FIG. 4.-February 1965. Radiograph of the chest showing some healing of the rib fractures.

Radiological investigations and follow-up. Her chest radiograph in November 1963 (Fig. 2) showed bilateral pseudo-fractures of her ribs and X-ray of her pelvis in October 1963 (Fig. 3) showed a very long Looser's zone on the right side of the pelvis. The right femoral neck was displaced upwards and this caused her waddling gait. Bone rarefaction was not marked.

The patient responded well to Vitamin $D$ by mouth. She was initially put on 50,000 units per day, and this dose was gradually increased to 150,000 units per day. By April 1964 she had lost her bone pain and her serum calcium was normal. She also received extra milk, potassium bicarbonate $1 \mathrm{~g}$. t.d.s and sodium bicarbonate 1 g. t.d.s. Her skeletal survey was repeated in February 1965 was $72 \mathrm{mg} . / 100 \mathrm{ml}$., Na 136, K 3.9, rib fractures while the appearance of her pelvis and femoral heads (Fig. 5) has improved remarkably. The improvement in bone density can also be seen on the lateral films of the spine (Figs. 6 \& 7). Blood urea in February 1965 was $72 \mathrm{mg} . / 100 \mathrm{ml}$., Na. 136, K 3.9, $\mathrm{Cl} 105$ and alkali serum $17 \mathrm{Meq} / 1$. The serum alkaline phosphatase had fallen to $15 \mathrm{~K}-\mathrm{A}$ units. The serum calcium was $9.5 \mathrm{mg} . / 100 \mathrm{ml}$. and the serum inorganic phosphate had risen to $4.5 \mathrm{mg} . / 100 \mathrm{ml}$. Repeat chromatography showed a similar pattern of excessive amino-aciduria.

On her present treatment she continues to remain well and pain-free. Her gait is now completely normal.

Family Study. The urines of the patients' five children, her mother, a brother and two sisters have all been examined by paper chromatography. In no case

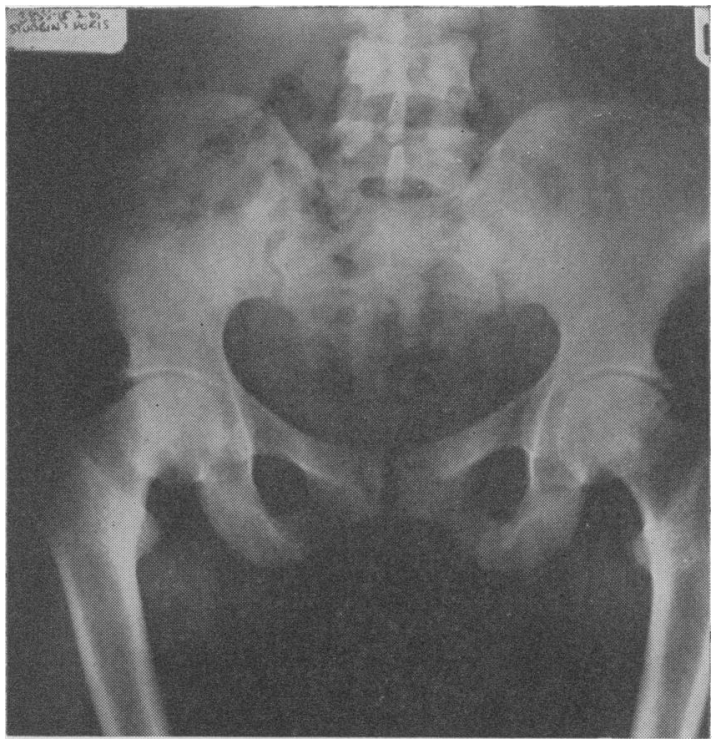

FIG. 5.-February 1965 , Radiograph of the pelvis, showing marked increase in bone density and disappearance of the Looser zone.

was there any evidence of excessive amino-aciduria. The blood urea, electrolytes, serum calcium, serum phosphates and alkaline phosphates of all these relatives were normal. Unfortunately, through lack of cooperation, these investigations were not carried out on two other brothers and one other sister of the patient.

\section{Discussion}

The patient described had all the features of the adult Fanconi syndrome, i.e. osteomalacia, amino-aciduria, hyposphataemia, glycosuria, proteinuria, systemic acidosis and hypokalaemia. In 1957 Wallis and Engle reviewed 18 patients with the adult Fanconi syndrome. In 1961 Ben-Ishay, Dreyfuss and Ullmann described a further case whose relatives had subclinical forms of the disease, and they noted six other cases in the literature. Stanbury and Lumb (1962) added four more, and Wilson and Yendt (1963) reported two further cases of the adult syndrome associated with nephrolithiasis. Aufranc, Jones and Harris (1964) described a further case under the title of "Multiple Pseudo-fractures', and this, together with our patient, brings the total number of adult cases to thirty-three.

The main features in our patient, and also in cases described in the literature, include onset in middle age, a long history of bone pain, difficulty in walking, weakness and a waddling gait. Multiple pseudo-fractures occurred in all eighteen cases reviewed by Wallis and Engle (1957) and this finding is a most valuable radiological clue.

The aetiology of the adult syndrome is often obscure; a few cases have been shown to occur in families, the incidence suggesting a Mendelian recessive gene (Linder, Bull and Grayce, 1949; Dent and Harris, 1951; Stanbury and Lumb, 1962; 


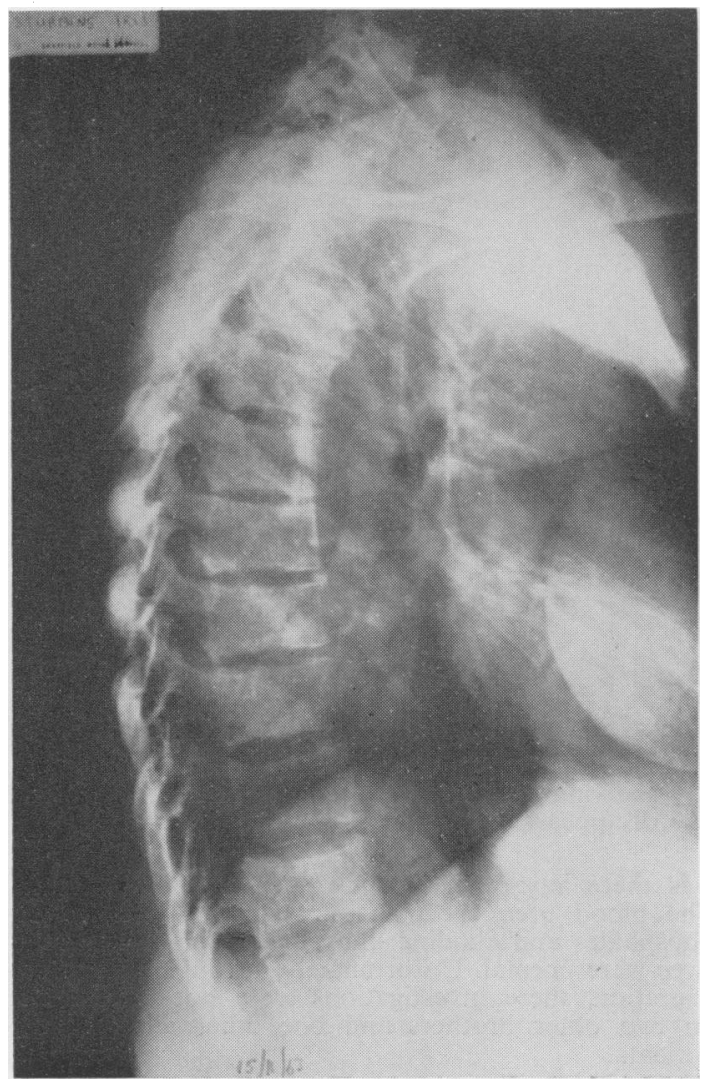

Fig. 6.-November 1963. Lateral X-ray of the spine. and Ben-Ishay and others, 1961). Other cases may be due to tubular damage in myelomatosis (Engle and Wallis, 1956; Costanza and Smoller, 1963), Wilson's disease (Morgan, Stewart, Lowe, Stowers and Johnstone, 1962), poisoning with certain heavy metals (Wallis and Engle, 1957; and Kazantzis, Flynn, Spowage and Trott, 1963), and to the ingestion of outdated tetracycline (Gross, 1963). The good prognosis in the adult type can be contrasted with that in cystinosis in children (Bickel, Bear, Astley, Douglas, Hickmans, Philpot, Smallwood, Scvelli and Teall, 1962) which is characterised by recessive inheritance, cystine storage and progressive renal failure. Conjunctival deposits of cystine in children can cause photophobia, but this has not been reported in the adult syndrome. The corneal crystals in our patient became less numerous after treatment. Because conjunctive biopsy was refused the nature of these crystals could not be established.

\section{Summary}

A further case of the so-called adult Fanconi syndrome is described. The biochemical and radiological features were fairly typical, but the finding of conjunctival and corneal crystals was most unusual. So far the Fanconi "trait" has not been discovered in the patient's family. Treatment with vitamin $\mathbf{D}$ and alkalis resulted in marked sympto-

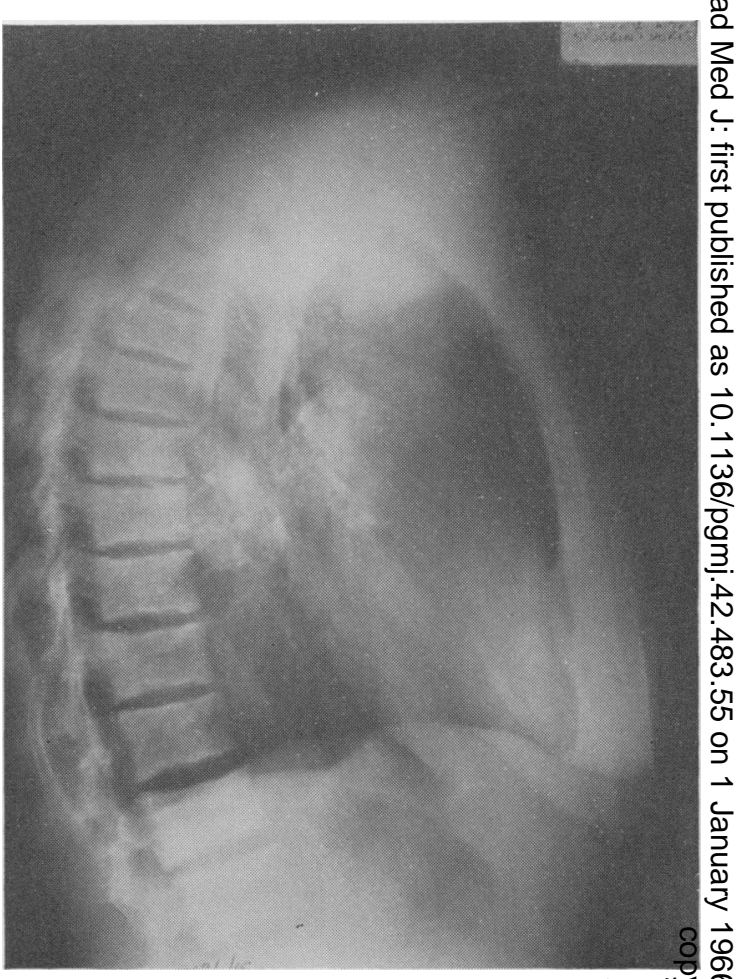

Fig. 7.-February 1965. Lateral X-ray of spixte, showing increase in bone density.

matic and radiological improvement. Hypercalcaemic renal failure will be the chief danger of continuous vitamin $\mathbf{D}$ therapy and careful biochemi-气 cal control will be necessary. Treatment with ${ }^{\Phi}$ phosphate and alkalis only (Wilson and Yendt, $\stackrel{2}{\overrightarrow{7}}$ 1963) could be used to avoid this hypercalcaemic윽 hazard.

My thanks are due to Professor C. H. Stuart-Harris for permission to publish this case and to Dr. G. Rㅇ. Newns who referred the patient. Also to Dr. To Lodge, Dr. A. Jordan and Mr. C. Dark for assistance in investigating this patient, and to Professor C. EDent who gave us his enthusiastic help. Tubular pro-3 tein investigations were carried out by Dr. F. V. Flynn.

\section{REFERENCES}

Aufranc, O. E., Jones, W. N., and Harris, W. H.o (1964): Multiple Pseudofractures, J. Amer. med. Ass., 190, 842.

Ben-IShaY, D., Dreyfuss, F., and UllmanN, T. D吾. (1961): Fanconi Syndrome with Hypouricemia in an Adult, Amer. J. med., 31, 793.

Bickel, H., BaAR, H. S., Astley, R., Douglas, A. S. N Finch, E., Harris, H., Harvey, C. C., Hickmanso E. M., Philpot, M. iC., SMallwood, W. C.心 Sevelli, J. M., and Teall, C. E. (1952): Cystineg Storage Disease with Aminoaciduria and Dwarfism (Lignac-Fanconi Disease), Acta paediat. (Uppsala) (Suppl. 90) 1.

BuTLER, E. A., and FlynN, F. V. (1958): The Protei nuria of Renal Tubular Disorders, Lancet, ii, 978.0 Costanza, D. J., and SMOller, M. (1963): Multiplēe Myeloma with Fanconi Syndrome, Amer. J. med. 34, 125 . 
Creeth, J. M., KeKWick, R. A., Flynn, F. V., HARRIS, H., and RoBSON, E. B. (1963): An Ultracentrifuge Study of Urine Proteins with Particular Reference to the Proteinuria of Renal Tubular Disorders, Clin. Chim. Acta, 8, 406.

DENT, C. E., and HaRris, H. (1951): The Genetics of Cystinuria, Ann. Eugen. (Lond.), 16, 60.

ENGLE, R. L. Jr., and Wallis, L. A. (1956): Multiple Myeloma and the Adult Fanconi Syndrome; Report of a Case with Crystal-like Deposits in the Tumour Cells and in the Epithelial Cells of the Kidney, Amer. J. med., 21, 5.

Gross, J. M., (1963): Fanconi Syndrome (Adult type) Developing Secondary to Ingestion of Outdated Tetracycline, Ann. intern. med., 58, 523.

Kazantzis, G., FlynN, F. V., Spowage, J. S., and TrotT, D. G. (1963): Renal Tubular Malfunction and Pulmonary Emphysema in Cadmium Workers, Quart. J. med., 32, 165.
Linder, G. C., Bull, G. M., and Grayce, I. (1949): Hypophosphatemic Glycosuric Rickets (Fanconi Syndrome) - Report of a Case with Retinitis Pigmentosa, Clin. Proc., 8, 1.

Morgan, H. G., Stewart, W. K., Lowe, K. G., STOWERS, J. M., and JOHNSTONE, J. H. (1962): Wilson's Disease and the Fanconi Syndrome, Quart. J. med., 31, 361 .

Stanbury, S. W., and Lumb, G. A. (1962): Metabolic Aspects of Renal Osteodystrophy, I. Medicine (Baltimore), 41, 1.

Wallis, L. A., and Engle, R. L. (1957): Adult Fanconi Syndrome. Review of Eighteen Cases, Amer. J. Med., 22, 13

Wilson, D. R., and YendT, E. R. (1963): Treatment of the Adult Fanconi Syndrome with Oral Phosphate Supplements and Alkali, Amer. J. Med., 35, 487.

\title{
A SOLITARY SECONDARY DEPOSIT IN THE PANCREAS FROM A CARCINOMA OF THE CERVIX
}

\author{
C. WASTEll, F.R.C.S. \\ Westminster Hospital, London, S.W.I
}

SECONDARY deposits in the pancreas from carcinomas elsewhere are quite commonly found but solitary secondary deposits are rare.

The following case is sufficiently unusual to warrant a brief report.

\section{Case Report}

A lady aged 66 was admitted to Westminster Hospital in August 1959 with a stage II carcinoma of the cervix. Biopsy revealed a moderately well differentiated carcinoma (Fig. 1) which was treated with two insertions of radium by the Stockholm technique and a course of external beam radiotherapy with the Theratron unit. A good recovery was made apart from persistent painful micturition, which was worse at night. One year later, at cystoscopy no evidence of recurrent growth was seen, there being some basal trigonitis only.

She remained well until July 1964, some five years after the cervical lesion was first treated, when she presented with a nine week history of jaundice. This was associated with back pain, weight loss, anorexia, dark urine and pale stools.

On Examination. The patient was deeply jaundiced and had obviously lost weight. The abdomen was slightly distended and the smooth, tender liver edge was palpable $8 \mathrm{~cm}$. below the costal margin. Beneath the liver the distended gall bladder could be felt. On pelvic examination the vault of the vagina was found to be obliterated by post-irradiation scarring but there was no evidence of recurrence of tumour.

Investigations: Total serum bilirubin $13.5 \mathrm{mg} . / 100$ $\mathrm{ml}$., Conjugated $9.3 \mathrm{mg}$., free $3.2 / \mathrm{mg}$. $/ 100 \mathrm{ml}$., Serum alkaline phosphatase 31 K.A. units, Prothrombin time: normal. SGOT 34 I.U., S.G.P.T. 19 I.U., Hb. 12.4 g./100 ml., Serum albumin 2.1 g. globulin

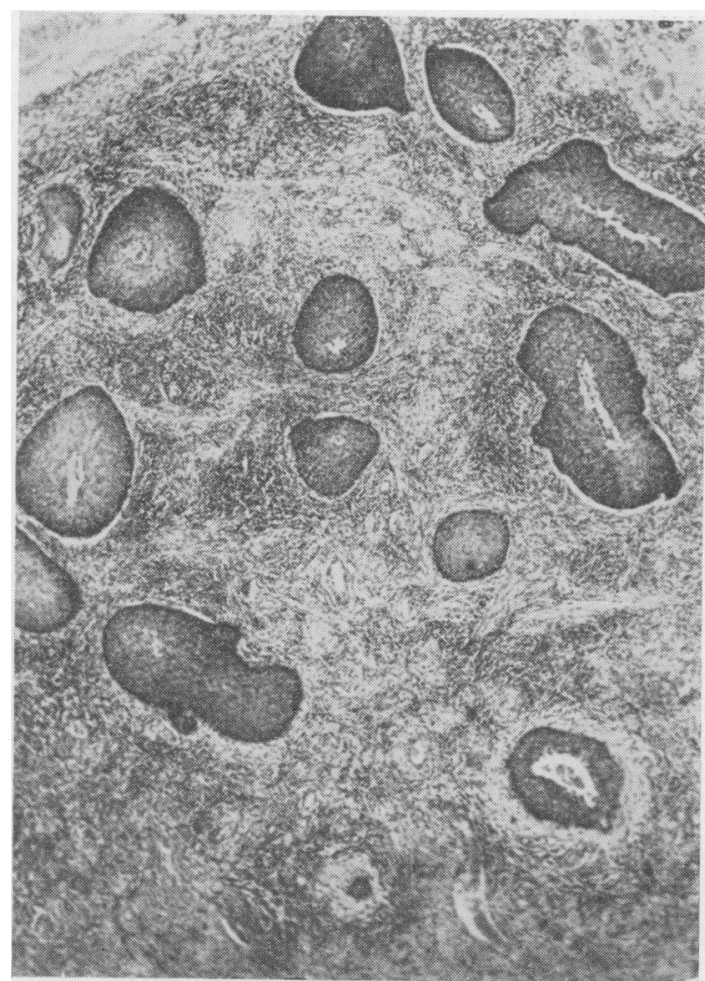

FIG. 1.-Section from biopsy of cervix taken in 1959 showing moderately well differentiated squamous carcinoma. (H. \& E. x 65). 